\title{
Factual Model of Internal Quality Assurance System of Private HIGHER EDUCATION INSTITUTIONS IN INDONESIA
}

\author{
Andi Mursidi $^{1)}$, Tri Joko Raharjo ${ }^{2)}$, Sugiyo ${ }^{3)}$, Arief Yulianto ${ }^{4)}$ \\ ${ }^{1)}$ STKIP Singkawang, Singkawang, Indonesia \\ E-mail: andimursidi@hotmail.com \\ ${ }^{2)}$ Universitas Negeri Semarang, Semarang, Indonesia \\ E-mail: trijokoraharjo@mail.unnes.ac.id \\ ${ }^{3)}$ Universitas Negeri Semarang, Semarang, Indonesia \\ E-mail:sgy11@mail.unnes.ac.id \\ ${ }^{4)}$ Universitas Negeri Semarang, Semarang, Indonesia \\ E-mail: ariefyulianto@mail.unnes.ac.id
}

\begin{abstract}
Quality has increasingly become an important success determiner for higher education institutions. The education quality highly depends on the quality of all management systems run by the higher education institutions. This research aims at explaining the factual model and identifying the main factors influencing the implementation and development of quality assurance system of private higher education institutions in West Kalimantan Province, Indonesia. Research and Development $(R \& D)$ method was used as the research methodology to develop the model. Data collection processes start by interviewing the stakeholders of internal quality assurance system at higher education institutions and then distributing questionnaires related to the implementation of internal quality assurance system at each higher education institution. The collected data was then analyzed and synthesized into the factual model. The obtained factual model consisted of three steps: planning, implementing, and evaluating the internal quality assurance. From this factual model, it is revealed that the implementation of internal quality assurance system of private higher education institutions in West Kalimantan Province, Indonesia has not completely become a part of higher education institution accountability orienting on the higher education quality assurance, but more on the temporary purposes, such as higher education institution accreditation purposes.
\end{abstract}

Keywords: Factual Model of Internal Quality Assurance; Internal Quality Assurance System; Higher Education Accountability

\section{INTRODUCTION}

Education quality is greatly necessary and essential since it has become the main purpose of education management. The quality and mechanism of sustainable development and standard improvement are greatly required in education management (Mursidi et al., 2019). Based on the Ministry of Research, Technology, and Higher Education of the Republic of Indonesia Regulation Number 62 Year 2016 last amended with the Ministry of Education and Culture of Republic of Indonesia Regulation Number 3 Year 2020, the higher education institution quality assurance standard is a systematic activity to improve the higher education institution quality assurance with planned and sustainable ways. The higher education institution quality is related to the fitness between the higher education institution managers and standards consisting of Higher Education National Standards and Higher Education Standards set by each higher education institution. The purpose of higher education institution quality assurance system is to guarantee the fulfillment of higher education institution standards in systematic and sustainable ways that the quality culture grows and develops at each higher education institution in Indonesia. 
Private higher education institutions in West Kalimantan manage both academic and vocational education institutions, have the excellence in producing graduates to become academicians, prospective teachers, professional workers, and researchers in both local and national level, as well as preserve and realize the national identity in the society. In 2020, there are 4,782 higher education institutions in Indonesia with 46 of which in West Kalimantan Province. The higher education forms in West Kalimantan Province consist of 5 universities, 2 institutes, 19 colleges, 2 polytechnics, and 18 academies. Those higher education institutions have performed both internal and external quality assurance (accreditation), (Pangkalan Data Perguruan Tinggi [Higher Education Database], 2020).

The internal quality assurance system of higher education institutions in West Kalimantan has so far been developed following the directions from the Ministry of Education and Culture. This system consists of three important operational elements: quality control, quality investigation, and quality evaluation. The system emphasizes on the improvement of input, process, and output quality. This system directs itself to the uniformed and sustainable quality improvement of the higher education performance (Mursidi et al., 2018).

However, some problems occurred when evaluating the internal quality based on the internal quality assurance of higher education institutions as reflected from the accreditation results of higher education institutions in West Kalimantan that only 17 higher education institutions had good (B) accreditation, while the other 29 higher education institutions had fair (C) accreditation. The Indonesian government has set the same quality standard. It means that theoretically those higher education institutions have the same quality standards, but the results were in fact different. This condition encourages the researcher to figure out the triggering factors.

\section{A. Research Questions}

1. What is the factual model of internal quality assurance system belonging to the private higher education institutions in West Kalimantan Province?

2. How is the evaluation of internal quality assurance system belonging to the private higher education institutions in West Kalimantan Province?

\section{B. Research Objectives}

a. Explaining the factual model of internal quality assurance system belonging to the private higher education institutions in West Kalimantan Province.

b. Evaluating the internal quality assurance system belonging to the private higher education institutions in West Kalimantan Province.

\section{LITERATURE REVIEW}

\section{The Concept of Quality Assurance in Higher Education}

Some researches and articles have been published since 1990, investigating and focusing on various aspects or quality problems in higher education — see Kanji and Tambi
(1998); Kanji, Malek, and Tambi (1999); Watty (2006); Becket, and Brookes (2008); Markulík and Nagyová (2009); Kohoutek (2009); Srikanthan and Dalrymple (2002); Stephenson and Yorke (2012); Zgodavova, Urbančíková, and Kisela (2015); Mursidi et al. (2018). Many different opinions in this field have been studied and continued until now. Some argued that the higher education quality is not clear and multi-dimensions — see Krause (2012) and Schindler et al. (2015). However, some others had different views and opinions related to higher education quality that can be used as references. For instance, Hossain and Hossain (2019) have conducted studies as the first initiatives reported in the higher education researches explaining the quality management as the multi-order hierarchical reflective model. The quality management system of higher education institutions can be explained as the third model, in which the quality management reflected by its education, administration, and social quality. Spencer-Matthews (2001) from the Business Faculty, University of Southern Queensland in Brisbane (Australia) has presented a case study using an action research as the efforts to implement the quality management system at the academic department of higher education institutions. He argued that the technical changes are easy to reach, while the quality cultural implementation only reached the false acceptation which had not been completely realized. There were critical discussions on the dynamics behind the development and internationalization of quality assurance policies and practices in higher education institutions in Slovenia, focusing on the formation of national quality assurance institutions, introduction to accreditation system, and development of quality assurance institutions in the studies realized by Komotar (2018). In Europe, when adapting what is known as Bologna process, a special document entitled Quality Assurance Standard and Guidance in the European Higher Education areas published by ENQA. J. Kohoutek (2009) has collected many interesting findings on the practical implementation of this document both strengths and weaknesses, dealing with the accreditation process as presented by Manatos and Huisman (2020).

Some strengths and weaknesses are attached to the higher education system in the world. Three elements consisting of research development and structure, quality, and capacity have been checked in the literature review by Ashour and Fatima (2016) in the United Arab Emirates (UAE). Those studies asserted that well-structured quality assurance system is one factor possibly improved the quality of education processes. The mixed method perspectives in the effectiveness determining investigation related to the quality assurance at higher education institutions were presented by Seyfried and Pohlenz (2018). The survey data from Germany higher education institutions was collected to analyze how far the quality managers consider their approach to the quality assurance is effective. Higher management supports from the higher education institution and cooperation with the other education institutions were the relevant prerequisites for bigger quality assurance effectiveness level, said Seyfried and Pohlenz (2018). 
The quality assessment is defined as a quality assessing process to what provided by an organization to satisfy its customers. The quality assurance system assessment in the higher education processes should become an integral part of the functioning university management system. Noaman et al. (2015) have presented the higher education quality assessment model proposed by Noaman et al. (2015) which resulted in an important recommendation for higher university authority to reach the requested qualified services.

The conducted discussions up to now related to the higher education quality and its measurement are due to the Maureen Tam's two important considerations (Tam, 2001) saying that the higher education activity center possibly maximizes the students' education development; and sustainable development possibly maximizes the students' learning and development which remain becoming the university's main objectives and concerns related to the higher education quality and measurement. The measurement of three quality dimensions (design quality, fitness quality, and performance quality) in higher education was performed by Widrick, Mergen, and Grant (2002). The proposed framework and discussed in this research were build based on the model developed by Mergen, Grant, and Widrick (2000). One set of measurement, together with some instruments to measure those three quality dimensions has been proposed. Many quality management initiatives, especially in service industries died since the higher education organizations failed to measure the result. The proposed framework enables the higher education institution to implement and measure the quality initiatives better (Widrick, Mergen, and Grant, 2002; Mergen, Grant, and Widrick, 2000).

An explorative study discussing the perceptions of university representatives related to the quality was conducted by four public universities in Kurdistan area, Irak by Atrushi and Woodfield (2018). Their research explored the higher education system from the perspectives of academic staffs and university leaders, focusing on the system quality evaluation. Besides, an obvious difference within the perceptions on the higher education quality was found among staffs, students, and employers (Dicker et al., 2018).

Bennett (2019) has analyzed possibilities, deficiencies, and benefits from the higher education quality assessments. Morosini et al. (2016) reminded us that the quality and performance measurement should become an important part of quality management at higher education. They proposed and organize a set of performance indicators in five categories including internationalization, management, learning quality, pedagogical innovations, and professional education or development.

\section{METHODOLOGY}

The purpose of this research is to identify, in the form of exploration, the implementation of higher education institution internal quality assurance system. To reach the goal, an explorative-qualitative research approach was conducted Hair et al. (2003) adopted based on a case study
Yin (2003). The need to be involved in this explorative research was due to the lack of research focusing on the demands of stakeholders, higher education participations and relevancy in establishing the quality assurance system in which there was only some or even no research agency that a researcher was required to tentatively figure out the reality in the field (Selltiz, Wrightsman, and Cook, 1976). Thus, this qualitative research approach with non-representative (but significant) samples obtained from the target population was proven the fittest to result in an initial finding related to the stakeholders and its relevancy represented by the institutions both individually and publicly.

The studies covered the factual model development concept. The data obtained from the previous studies was analyzed and synthesized to form the evaluation approach related to the internal quality assurance system implemented by the higher education institutions. The approach elements covered planning, implementation, and evaluation of internal quality assurance system. The research was conducted due to the Research and Development (R\&D) principles. This Research and Development methodology was in line with the factual model development process.

The implementation of factual model development research for this internal quality assurance system of higher education was conducted with the following working stages: (1) analyzing the documents, researches, concepts, and theories related to the quality factual model, indicators, and criteria of higher education; (2) interviewing experts to obtain information related to conditions, problems, and obstacles in implementing the internal quality assurance and formulate the factual model of internal quality assurance system; (3) synthesizing the information analysis result above to develop the factual model.

Analysis and synthesis were conducted on models, indicators, and criteria of internal quality assurance system implementation. Analysis and synthesis covered 5 private higher education institutions in West Kalimantan Province, Indonesia. Concept analysis to prepare the factual model for the internal quality assurance system of higher education was based on four education evaluation standard instruments; utility standard, fitness standard, propriety standard, and accuracy standard (Stufflebeam and Shinkfield, 1990).

For the data accuracy obtained, the researcher also distributed the questionnaires to 50 respondents from 5 higher education institutions to measure the implementation of private higher education institutions' internal quality assurance systems in West Kalimantan Province. The questionnaire has been tested based on its validity and reliability, while the measurement of internal quality assurance system implementation at private higher education institutions in West Kalimantan province was conducted using a frequency testing.

The information of interviews conducted on 5 respondents as persons in charge for quality assurance from 5 higher education institutions as the research samples. The information was related to conditions, problems, and obstaclesin implementing the internal quality assurance and 
factual model required for the internal quality assurance system.

\section{IV.RESULTS AND DISCUSSION}

\section{A. Results}

The research result was presented in the form of factual model by including the following elements: (1) internal quality planning, (2) quality implementation, follow up and evaluation, and (3) sustainable quality improvement. The internal quality assurance system process based on the frequency testing data processing due to the questionnaires distributed to 50 respondents from 5 higher education institutions showed the responses with the answers of highly disagree by $0 \%$, disagree by $44.4 \%$, neutral by $8 \%$, agree by $24.4 \%$ and highly agree by $63.2 \%$. Thus, it can be concluded that most respondents agreed with the implementation of quality assurance at higher education institutions. The data obtained from this frequency testing was then integrated with the results of interview, document, and observation tracing that the factual model of internal quality assurance system at private higher education institutions in West Kalimantan Province was eventually arranged.

There are three problems to discuss: (1) factual model development, (2) data collection instrument, analysis, and summary, and (3) planning, implementation, and evaluation aspect related to the internal quality assurance system.

a. Factual Model Development

In this research, the factual model was developed through the experts' critics, suggestions, and data collection results from the higher education institutions. The factual model development in this research was in accordance with the result of research conducted by Yeamsang (2007) in which the model was developed through the initial studies on state of knowledge management. This research was also in accordance with the result of research conducted by Cheunchey (2007) that the researcher developed the model from the previously related literature studies. He then analyzed and synthesized the collected model elements. Besides, this research was in accordance with the result of research conducted by Saisophon (2007) who completed the model by validating, trying, and testing the efficiency, and then completed the model. The factual model developed was as presented in Fig. 1.

The internal quality assurance system planning aspect of private higher education institutions in West Kalimantan Province showed that those higher education institutions have not had good quality standards since they had no preliminary data (baseline), no partnership and the stakeholders had poor commitments in developing good quality culture. Consequently, the quality assurance planning process at the study programs and higher education institutions were not well synchronized that the accreditation results were less optimum.
Meanwhile in the implementation aspect, since the planning was not good, the quality assurance documents were only used as the accreditation documents and never used as the implementation of good quality culture. Moreover, the accreditation did not precisely measure in details: what quality standard was actually implemented, how was the implementation of that quality standard, and how the quality auditing processes were made. The impact was that the accreditation result was less optimum.

The quality evaluation aspect was in fact not yet implemented, if the incidental quality auditing result has not been used as input materials for the quality standard improvement. Thus, the implementation of internal quality assurance system has not impacted on the performance improvement at the study programs and higher education institutions.

\section{B. Discussion}

Similar findings between this research and the previous ones (Hossain and Hossain, 2019; Komotar, 2018; Manatos and Huisman, 2020; Mursidi et al., 2018; Seyfried and Pohlenz, 2018) were resulted from the following factors:

1) Education standard specification enables all internal staff members adjust with their specified responsibilities.

2) Education management development planning is focused on higher education institutions' education standards. It is essential to make planning since planning is the first step to follow a series of steps and to effectively reach the goal.

3) Administration management and information system help encourage, support, facilitate the internal quality assurance.

4) Most education management development planning elements are followed.

5) Follow up management and education quality assessment indicating the assessment and study improvement of education quality were presented in the evaluation reports. Assessing and studying the education quality are important mechanisms to activate the improvement and feedback.

6) The internal quality evaluation based on the education standards results in better understanding between the managers and lecturers. Consequently, they can effectively perform the internal quality evaluation.

7) The internal quality evaluation annual report is a good factor, yet not concretely used and published since staffs probably have no ability to write the repots or instructions when those are not clearly explained.

8) Sustainable education quality improvement promotion is one factor required to develop and assess the education quality assurance system performance. 


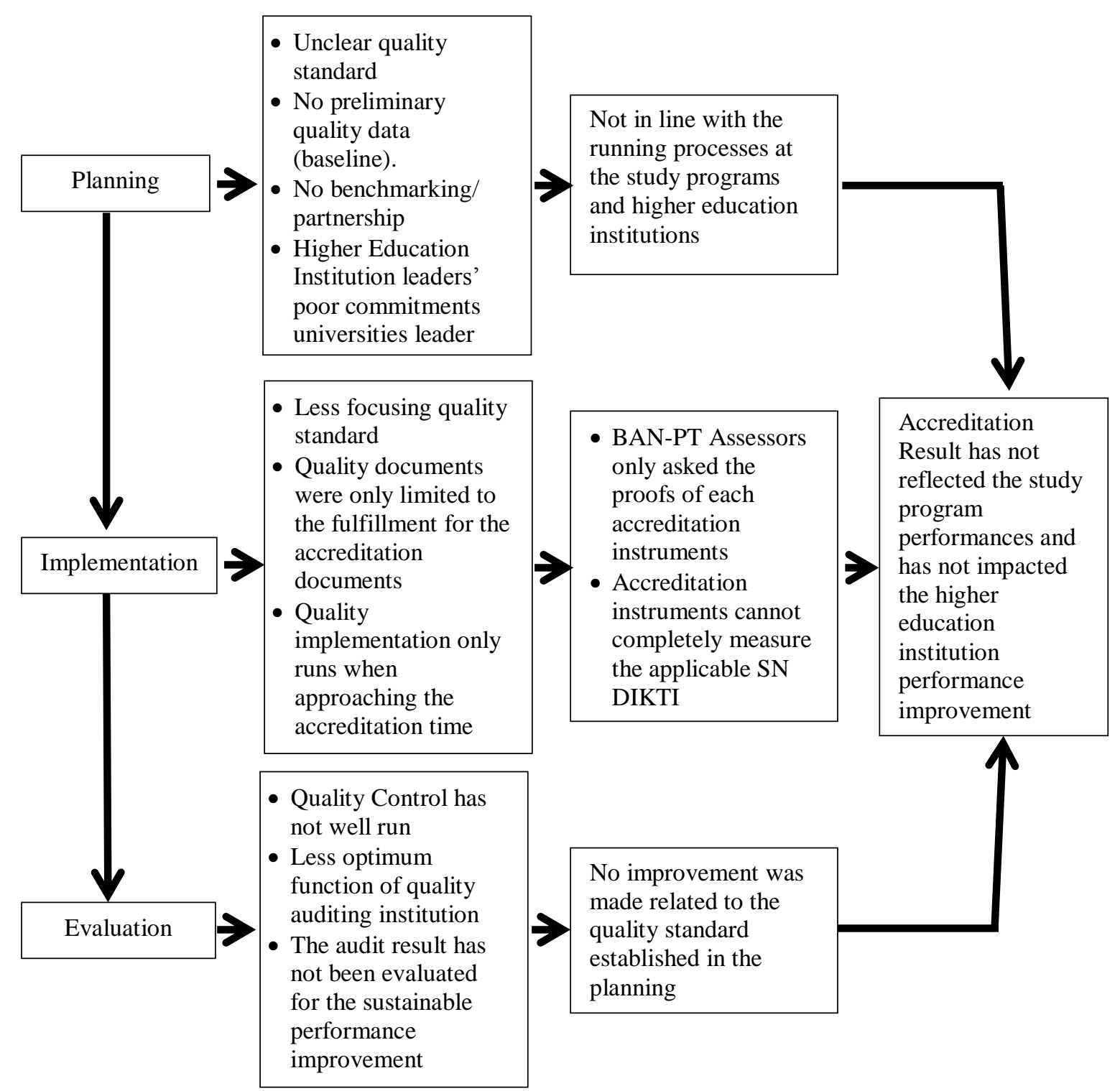

Figure 1: Factual Model of Internal Quality Assurance System of Private Higher Education in West Kalimantan Province Source: (Processed) Research Results

To follow all factual model organization processes, the researcher simultaneously discussed the steps used in the designed factual model. Conceptual and theoretical studies on the evaluation instrument creation and development were made. The concept of factual model development and evaluation instruments of internal quality assurance system implementation at higher education institutions in this research was based on that proposed by Gulicson (2008) asserting that there are four evaluation standard instruments; utility standard, fitness standard, propriety standard, and accuracy standard as well as the implementation of internal quality assurance system at STKIP Singkawang (Mursidi et al., 2018). This research result was also in accordance with the concept proposed by Davies related to indicators and evaluation criteria (Pupat, 1972) as well as the internal quality assurance system development of higher education (Mursidi et al., 2019). The evaluation criteria in this research were classified into scientific criteria, performance criteria, and score criteria. The model evaluation approach was consistent with the six approaches (Worthen and Sander, 1973).

The evaluation instrument characteristics in this research were in accordance with the concept proposed by Popham (1999) stating that those instruments should have validity, reliability, discrimination, objectiveness, difficulty, exemplification, search, commonness, and efficiency. The obtained data showed that most internal quality assurance system results were at the "medium" level. This is in accordance with the external quality assurance results (accreditation results). Thus, it can be concluded that since most higher education institutions do not completely perform the Plan-Do-Check-Act (PDCA) cycles, they also have less follow up systems and assessments as well as awareness on the importance of internal quality assurance. 


\section{CONCLUSIONS}

\section{A. Conclusions}

a. The factual model organized based on the field findings show that the higher education quality assurance is still only for the temporary purposes, such as accreditation purposes, not as the higher education institutions' efforts to guarantee their accountabilities.

b. The internal quality assurance system implementation of private higher education institutions in West Kalimantan Barat province shows many weaknesses, such as poor follow up systems, archiving systems, awareness, evaluation understanding, administrative management system and standards that improvements are greatly required.

c. It is important to follow up and evaluate the mechanisms regularly related to all quality assurance standards. Besides, to evaluate the internal quality assurance of higher education institutions, all staffs from any level are required to improve their awareness on the importance of quality assurance. Those staffs responsible for the quality assessment system should be well managed and clear.

\section{B. Suggestions}

Based on the significances and problems in the internal quality assurance system implementation as mentioned above, the internal quality assurance system should be well developed. To develop this model, the evaluation concepts and theories orienting on the system decisions are included. Some evaluation techniques orienting on collaboration, such as an approach focusing on the utilization, empowerment evaluation, and collaborative evaluation are also used. The approach focusing on the utilization aims at obtaining benefits possibly earned by the evaluated organizations. The approach process focusing on the utilization requires collaboration. Collaboration is an effort to collect all groups of stakeholders to participate in organizing the quality assurance standards of their higher education institutions.

A constructive model development can be performed in the next research stage since the constructive model is considered as on factor helping the internal quality assurance of higher education institutions to achieve their goals.

\section{REFERENCES}

Ashour, S.; Fatima, S.K. (2016). Factors favouring or impeding building a stronger higher education system in the United Arab Emirates. J. High. Educ. Policy Manag, 38, 1-16. [CrossRef]

Atrushi, D.S.; Woodfield, S. (2018). The quality of higher education in the Kurdistan Region of Iraq. Br. $J$. Middle East. Stud. 45, 1-16. [CrossRef]

Becket, N.; Brookes, M. (2008). Quality Management Practice in Higher Education-What Quality Are We Actually Enhancing? J. Hosp. Leis. Sport Tour. Educ. 7, 40-54. [CrossRef]

Bennett, D.C. (2019). Assessing Quality in Higher Education. Available online: https: //www.aacu.org/publications- research/periodicals/assessing-quality-highereducation (accessed on November 7, 2019).

Cheunchey, Chanoknart. (2007). A Model for Continuing Education Management in Private Higher Education Institutions. Dissertation of Adult Education. Srinakarinwirot University: Thailand.

Dicker, R.; García, M.; Kelly, A.; Mulrooney, H.M. (2018) What does 'quality' in higher education mean? Perceptions of staff, students and employers. Stud. High. Educ, 44, 1425-1441. [CrossRef]

Gulicson, Arlen. (2008). The Personnel Evaluation Standards: How to Assess Systems for Evaluating, Corwing Publishing, USA

Hair Jr., J.; Babin, B.; Money, A.; Samouel, P. (2003). Essentials of business research methods. New Jersey: John Wiley \& Sons.

Hossain, M.M.; Hossain, M.A. (2019). Understanding the Quality Management of Private Universities in Bangladesh: A Hierarchical Model. Qual. Manag. J., 26, 191-206. [CrossRef]

Kanji, G.K.; Malek, A.; Tambi, B.A. (1999). Total quality management in UK higher education institutions. Total. Qual. Manag. 10, 129-153. [CrossRef]

Kanji, G.K.; Tambi, A.M.A. (1998). Total quality management and higher education in Malaysia. Total. Qual. Manag. 9, 130-132. [CrossRef]

Kohoutek, J. (2009). Studies on Higher Education. In Implementation of the Standards and Guidelines for Quality Assurance in Higher Education in the Central and East-European Countries-Agenda Ahead; UNESCO-CEPES: Bucharest, Romania; p. 321.

Komotar, M.H. (2018). The evolutionary dynamics of quality assurance systems in European higher education: The view from Slovenia. Qual. High. Educ, 24, 203-220. [CrossRef]

Krause, K.-L.D. (2012). Addressing the wicked problem of quality in higher education: Theoretical approaches and implications. High. Educ. Res. Dev., 31, 285297. [CrossRef]

Manatos, M.J.; Huisman, J. (2020). The use of the European Standards and Guidelines by national accreditation agencies and local review panels. Qual. High. Educ., 26, 48-65. [CrossRef]

Markulík, Š.; Nagyová, A.; Mokrišová, A. (2009). Quality management system higher education area. In Form Integrated Management System towards Generic Management Systems: Approaches from Slovakia and Germany; Shaker Verlag: Herzogenrath, Germany; pp. 59-64.

Mergen, E.; Grant, D.; Widrick, S.M. (2000). Quality management applied to higher education. Total. Qual. Manag., 11, 345-352. [CrossRef]

Morosini, M.C.; Maria Barbosa Fernandes, C.; Leite, D.; Dal Pai Franco, M.E.; Da Cunha, M.I.; Aguiar Isaia, S.M. (2016). Quality of Higher Education and the Complex Exercise of Proposing Indicators. Revista Brasiliana de Educacao. 2016. No. 64. Available 
online: https: //www.scielo.br (accessed on January 12, 2020).

Mursidi, Andi., \& Soeharto, S. (2016). An introduction: evaluation of quality assurance for higher educational institutions using Rasch model. Journal of Education, Teaching and Learning, 1(1), 1-6.

Mursidi, Andi., Murdani, E., Ting, I.-H., \& Wu, J. C. (2019). Development of internal quality assurance model in higher education institution. Proceedings of the 10th International Conference on E-Education, EBusiness, E-Management and E-Learning, 264269.

Mursidi, Andi., Setyowati, R., \& Wulandari, F. (2018). The Strategies to build quality culture based on knowledge management in higher education. International Conference on Knowledge Management in Organizations, 452-463.

Mursidi, Andi., Slamet, A., Raharjo, T. J., \& Rifai, A. (2018). Embedding a Mental Attitude to Build Quality Culture in STKIP Singkawang Using DIECU Model. Proceedings of the 2018 International Conference on Education Technology Management, 24-27.

Mursidi, Andi., Soeharto, S., Setyowati, R., Ting, I., Sundiman, D., \& Sabran, S. (2018). Model of Internal Quality Assurance System (SPMI) in STKIP SIngkawang. Sinergi: Jurnal Ilmiah Ilmu Manajemen, $8(1)$. https://doi.org/10.25139/sng.v8i1.671

Noaman, A.Y.; Ragab, A.H.M.; Madbouly, A.I.; Khedra, A.M.; Fayoumi, A.G. (2015). Higher education quality assessment model: Towards achieving educational quality standard. Stud. High. Educ., 42, 23-46. [CrossRef]

Pangkalan Data Perguruan Tinggi. https://pddikti.kemdikbud.go.id (Accessed on January 4, 2020).

Peraturan Menteri Pendidikan dan Kebudayaan Republik Indonesia No. 3 tahun 2020 tentang Standar Penjaminan Mutu Pendidikan Tinggi.

Peraturan Menteri Riset, Teknologi dan Pendidikan Tinggi Republik Indonesia, No. 62 Tahun 2016 tentang Standar Penjaminan Mutu Pendidikan Tinggi.

Popham, W. James. (1999). Modern Education Measurement. Englewood Cliffs, New Jersey: Pretice-Hall.

Pupat, Phadungchai. (1972). A Comparison of Reliability and Discrimination Power of an English Test Scored by the Conventional. Dissertation of Eductional Measurement. Khon Kaen University: Thailand.

Saisophon, Phiyapong. (2007). Participatory Learning Model Development of Life Skills Development Subject 1 Under Basic Education Curriculum B.E.2544 for
Enhancing Life Skills of Nonformal Education Students in Central Correctional Institution. Dissertation of Adult Education. Srinakarinwirot University: Thailand.

Schindler, L.; Puls-Elvidge, S.; Welzant, H.; Crawford, L. (2015). Definitions of Quality in Higher Education: A Synthesis of the Literature. High. Learn. Res. Commun, 5, 3. [CrossRef]

Selltiz, C., Wrightsman, L., \& Cook, S. (1976). Research methods in social relations. 3 ed. New York: Holt, Rinehart \& Winston

Seyfried, M.; Pohlenz, P. (2018). Assessing quality assurance in higher education: Quality managers' perceptions of effectiveness. Eur. J. High. Educ. 8, 258-271. [CrossRef]

Spencer-Matthews, S. (2001). Enforced Cultural Change in Academe. A Practical Case Study: Implementing quality management systems in higher education. Assess. Evaluation High. Educ. 26, 51-59. [CrossRef]

Srikanthan, G.; Dalrymple, J.F. (2002). Developing a Holistic Model for Quality in Higher Education.Qual. High. Educ. 8, 215-224. [CrossRef]

Stephenson, J.; Yorke, M. (2012). Capability and Quality in Higher Education; Routledge: London, UK,; p 224.

Stufflebeam, D. L., \& Shinkfield A. J. (1990). Evaluation Theory, Models and Applications. San Francisco: Jossey-Bass.

Tam, M. (2001). Measuring Quality and Performance in Higher Education. Qual. High. Educ., 7, 47-54. [CrossRef]

Watty, K. (2006). Want to Know About Quality in Higher Education? Ask an Academic. Qual. High. Educ. 12, 291-301. [CrossRef]

Widrick, S.M.; Mergen, E.; Grant, D. (2002). Measuring the dimensions of quality in higher education. Total. Qual. Manag. 13, 123-131. [CrossRef]

Worthen, B.R. and Sanders, J.R. (1973) Educational evaluation: Theory and practice. Worthington, USA.

Yeamsang, Tirawar. (2007). Developing a Khowledge Management Model of the Office of Mahasarakham Educational Service Area Zone 1. Dissertation of Educational Adminstation and Development. Mahasarakham University: Thailand.

Yin, R. (2003). Case study research: Design and Methods. 3 ed. Thousand Oaks, California: Sage Publications.

Zgodavova, K.; Urbančíková, N.; Kisela, M. (2015). Enhancement of the Quality Assurance Model at the Slovak University: Case Study. Qual. Innov. Prosper. 19, 1. [CrossRef] 